\title{
Original
}

\section{Overall usefulness of newborn screening for congenital hypothyroidism by using free thyroxine measurement}

\author{
Akiko Soneda $^{1)}$, Masanori Adachi ${ }^{1), 2)}$, Koji Muroya ${ }^{1)}$, Yumi Asakura ${ }^{1)}$, Yuji Yamagami ${ }^{2), 3)}$ and \\ Fumiki Hirahara ${ }^{2), 4)}$ \\ 1) Department of Endocrinology and Metabolism, Kanagawa Children's Medical Center, Yokohama 232-8555, Japan \\ 2) Neonatal Mass-screening Committee, Kanagawa Prefecture Medical Association, Yokohama 231-0037, Japan \\ 3) Kanagawa Health Service Association, Yokohama 236-8530, Japan \\ 4) Department of Obstetrics and Gynecology, Yokohama City University School of Medicine, Yokohama 236-0004, Japan
}

\begin{abstract}
In Kanagawa Prefecture, Japan, simultaneous measurements of free T4 (FT4) and TSH levels are performed during newborn screening for congenital hypothyroidism $(\mathrm{CH})$. FT4 measurement enables the detection of $\mathrm{CH}$ of central origin (CH-C), the incidence of which is estimated to be 1 in 30,833 live births in Kanagawa Prefecture. In this study, we aimed to evaluate the efficacy of FT4 screening when transient $\mathrm{CH}-\mathrm{C}$ and thyroidal $\mathrm{CH}(\mathrm{CH}-\mathrm{T})$ with delayed TSH elevation are included as screening targets. Data collected on $\mathrm{CH}-\mathrm{C}$ patients using a regional survey, as well as data from a database created by a screening organization, were used. Of the $24 \mathrm{CH}-\mathrm{C}$ patients who had been born in Kanagawa Prefecture between 1999 and 2008, a positive screening result for FT4 $(<0.7 \mathrm{ng} / \mathrm{dL})$ was obtained in 13 newborns; of these, 12 were identified solely through newborn screening. Of the 113 patients for whom positive screening results were obtained during the study period, 5 and 6 were found to have transient $\mathrm{CH}-\mathrm{C}$ and $\mathrm{CH}-\mathrm{T}$ with delayed TSH elevation, respectively. Remarkably, 4 out of 5 patients with transient $\mathrm{CH}-\mathrm{C}$ and all patients with $\mathrm{CH}-\mathrm{T}$ with delayed TSH elevation were diagnosed through the evaluation of low FT4 at screening. These results indicate that the use of this FT4 screening system facilitates the identification of transient $\mathrm{CH}-\mathrm{C}$ and $\mathrm{CH}-\mathrm{T}$ with delayed TSH elevation, thus justifying the inclusion of these entities as screening targets.
\end{abstract}

Key words: Congenital hypothyroidism, Free thyroxine, Neonatal screening, Thyroid stimulating hormone, Transient central hypothyroidism

THE SCREENING of newborns for congenital hypothyroidism $(\mathrm{CH})$ is now routinely conducted in many countries and aims towards the early detection and treatment of one of the most common preventable causes of intellectual retardation [1-4]. The most common strategy for newborn screening is a primary TSH with backup T4 strategy, which involves an initial TSH measurement, followed by $\mathrm{T} 4$ measurement if high TSH levels are detected $[3,4]$. The rationale for this strategy is based on the fact that most $\mathrm{CH}$ cases have a thyroidal origin (CH-T), such as thyroid gland dysgenesis or thyroid hormone synthesis defects [5].

Kanagawa Prefecture in Japan, however, has

Submitted Mar. 30, 2014; Accepted Jul. 12, 2014 as EJ14-0143 Released online in J-STAGE as advance publication Aug. 2, 2014 Correspondence to: Masanori Adachi, M.D., Department of Endocrinology and Metabolism, Kanagawa Children's Medical Center, Mutsukawa 2-138-4, Minami-ku, Yokohama 232-8555, Japan. E-mail: madachi@mars.sannet.ne.jp adopted a strategy of simultaneous measurement of free T4 (FT4) and TSH levels in all newborns, which is referred to as a primary FT4 and TSH strategy. Screening of FT4 levels has enabled the detection of a significant number of cases of $\mathrm{CH}$ of central origin (CH-C), the incidence of which has been estimated to be 1 in 30,833 live births in our previous study [6].

Another possible advantage of screening using FT4 measurement is that it enables the detection of transient $\mathrm{CH}-\mathrm{C}$, which usually develops in newborns with hyperthyroid mothers [7-11]. Although hypothyroidism under these conditions may be self-limiting, it can lead to intellectual disabilities if it is not detected and treated [11]. In addition, FT4 measurement may enable the identification of newborns with $\mathrm{CH}-\mathrm{T}$ with delayed TSH elevation - found mainly in premature and/or low birth weight (LBW) newborns - who may not be identified by a primary TSH strategy [2, 4, 12-14].

In the present study, we aimed to evaluate the effi- 
cacy of screening by using FT4 measurement, when transient $\mathrm{CH}-\mathrm{C}$ and $\mathrm{CH}-\mathrm{T}$ with delayed TSH elevation are included as target entities in the screening system.

\section{Materials and Methods}

This study has been approved by the Institutional Review Board of Kanagawa Children's Medical Center and followed the World Medical Association Declaration of Helsinki regarding ethical conduct of research involving human subjects.

\section{Newborn screening system}

The details of our screening methods were described in a previous report [6]. In brief, the screening procedure is based on the determination of TSH and FT4 levels in dried blood spots obtained 4-7 days (median, 5 days) after birth. Newborns with high TSH levels ( $\geq 30$ $\mu \mathrm{IU} / \mathrm{mL}$ of serum) are immediately referred to one of the regional pediatric endocrine units. A second filter paper sampling is requested in those with borderline TSH levels (15-30 $\mu \mathrm{IU} / \mathrm{mL}$ of serum) or low FT4 levels $(<0.7 \mathrm{ng} / \mathrm{dL}[9.0 \mathrm{pmol} / \mathrm{L}]$ of serum). If the results again indicate high TSH level $(\geq 15 \mu \mathrm{IU} / \mathrm{mL})$ or low FT4 level $(<0.7 \mathrm{ng} / \mathrm{dL})$, the newborn is referred for a thorough evaluation. In the current study, TSH levels in filter paper samples were determined using the enzymelinked immunosorbent assay with mouse monoclonal antihuman TSH antibodies (Eiken Chemical Co. Ltd., Tochigi, Japan), whereas FT4 levels in filter paper samples were determined using ENZAPLATE N-FT4 (Siemens Healthcare Diagnostics K.K., Tokyo, Japan).

\section{Data collection}

The first step in the data collection was conducting a survey regarding $\mathrm{CH}-\mathrm{C}$, as has been described previously [6]. In brief, through 2008 and 2009, a questionnaire was sent to all 139 hospitals with a pediatric section in Kanagawa Prefecture requesting them to report the number of and clinical data regarding the $\mathrm{CH}-\mathrm{C}$ cases born between 1999 and 2008 .

The next step involved searching through the database compiled by the Neonatal Mass-screening Committee (NMC) of the Kanagawa Prefecture Medical Association (KPMA). This database contained all the screening results and details of the first-line investigation performed at the pediatric endocrine units for screening-positive patients. Cases diagnosed as either $\mathrm{CH}-\mathrm{C}$ or transient $\mathrm{CH}-\mathrm{C}$ were identified for further anal- ysis. Transient $\mathrm{CH}-\mathrm{C}$ was defined as a case in which $\mathrm{CH}-\mathrm{C}$ was once suspected because the FT4 level was $<0.7 \mathrm{ng} / \mathrm{dL}$ in both the first and second samples and in which the administration of L-thyroxine was performed until recovery of thyroid function. In addition, we identified $\mathrm{CH}-\mathrm{T}$ cases with delayed TSH elevation, defined as $\mathrm{CH}-\mathrm{T}$ cases in whom both FT4 level $<0.7 \mathrm{ng} / \mathrm{dL}$ (positive result) and TSH level $<15 \mu \mathrm{IU} / \mathrm{mL}$ (negative result) were recorded at least once during screening.

\section{Results}

\section{$\mathrm{CH}-\mathrm{C}$}

As we previously reported [6], $24 \mathrm{CH}-\mathrm{C}$ patients who had been born in Kanagawa Prefecture between 1999 and 2008 were identified, among whom 13 patients had a positive screening result for FT4 level $(<0.7 \mathrm{ng} / \mathrm{dL})$ (Table 1). Of these 13 patients, 12 were identified solely through newborn screening, whereas the other patient with hypopituitarism was diagnosed after presenting with a shock state along with the measurement of a positive FT4 level result $(0.58 \mathrm{ng} / \mathrm{dL})$ during screening.

\section{Transient $\mathrm{CH}-\mathrm{C}$}

Review of the NMC-KPMA database revealed that out of the 740,003 newborns screened between 1999 and 2008, 113 were suspected to have $\mathrm{CH}-\mathrm{C}$ because of the measurement of an FT4 level $<0.7 \mathrm{ng} / \mathrm{dL}$. Among these 113 cases, 5 cases were ultimately diagnosed with transient $\mathrm{CH}-\mathrm{C}$. The other patients were diagnosed with $\mathrm{CH}-\mathrm{C}$ (including indefinite cases; $\mathrm{n}=20$ ), low FT4 due to prematurity $(\mathrm{n}=23)$, critical illness ( $=26)$, thyroxine-binding globulin deficiency $(\mathrm{n}=12)$, and undetermined condition $(\mathrm{n}=27)$. All 5 patients diagnosed with transient $\mathrm{CH}-\mathrm{C}$ were born to mothers with Graves' disease. Table 2 provides detailed data regarding each patient.

\section{CH-T with delayed TSH elevation}

Of the 113 cases in the NMC-KPMA database in which $\mathrm{CH}-\mathrm{C}$ was suspected, 6 were identified as $\mathrm{CH}-\mathrm{T}$ with delayed TSH elevation. Table 3 summarizes their background data and thyroid function test results both at screening and during the thorough evaluation. All 6 patients were treated in the neonatal intensive care unit (NICU) at the time of screening because of various indications. Four patients were either preterm newborns with a gestational age of $<37$ weeks or LBW newborns. 
Table 1 CH-C patients with low FT4 levels in newborn screening

\begin{tabular}{|c|c|c|c|c|c|c|c|c|c|c|c|c|c|c|c|}
\hline \multirow{3}{*}{$\begin{array}{l}\text { Pt. } \\
\text { No. }\end{array}$} & \multirow{3}{*}{$\begin{array}{l}\text { Birth } \\
\text { year }\end{array}$} & \multirow{3}{*}{ Sex } & \multirow{3}{*}{ Entity } & \multicolumn{4}{|c|}{ Screening results } & \multirow{3}{*}{$\begin{array}{l}\text { Pt. } \\
\text { No. }\end{array}$} & \multirow{3}{*}{$\begin{array}{l}\text { Birth } \\
\text { year }\end{array}$} & \multirow{3}{*}{ Sex } & \multirow{3}{*}{ Entity } & \multicolumn{4}{|c|}{ Screening results } \\
\hline & & & & \multicolumn{2}{|c|}{ First sample } & \multicolumn{2}{|c|}{ Second sample } & & & & & \multicolumn{2}{|c|}{ First sample } & \multicolumn{2}{|c|}{ Second sample } \\
\hline & & & & $\begin{array}{c}\text { TSH } \\
(\mu \mathrm{IU} / \mathrm{mL})\end{array}$ & $\begin{array}{c}\text { FT4 } \\
\text { (ng/dL) }\end{array}$ & $\begin{array}{c}\text { TSH } \\
(\mu \mathrm{IU} / \mathrm{mL})\end{array}$ & $\begin{array}{c}\text { FT4 } \\
\text { (ng/dL) }\end{array}$ & & & & & $\begin{array}{c}\text { TSH } \\
(\mu \mathrm{IU} / \mathrm{mL})\end{array}$ & $\begin{array}{c}\text { FT4 } \\
\text { (ng/dL) }\end{array}$ & $\begin{array}{c}\text { TSH } \\
(\mu \mathrm{IU} / \mathrm{mL})\end{array}$ & $\begin{array}{c}\text { FT4 } \\
\text { (ng/dL) }\end{array}$ \\
\hline 1 & 2003 & $\mathrm{M}$ & IH & 5.9 & 0.14 & 2.4 & 0.48 & 8 & 2008 & $\mathrm{M}$ & $\mathrm{IH}$ & 3.0 & 0.68 & 1.3 & 0.68 \\
\hline 2 & 2004 & M & MPHD & 3.1 & 0.48 & 1.8 & 0.50 & 9 & 2008 & M & $\mathrm{IH}$ & 4.6 & 0.43 & 1.1 & 0.66 \\
\hline 3 & 2005 & M & MPHD & 4.1 & 0.55 & 4.7 & 0.38 & 10 & 2008 & M & $\mathrm{IH}$ & 1.5 & 0.69 & 2.5 & 0.53 \\
\hline 4 & 2005 & M & MPHD & 3.5 & 0.37 & 3.1 & 0.62 & 11 & 2008 & $\mathrm{M}$ & $\mathrm{IH}$ & 0.7 & 0.21 & 1.7 & 0.50 \\
\hline 5 & 2006 & M & IH & 2.2 & 0.60 & 3.3 & 0.47 & 12 & 2008 & M & $\mathrm{IH}$ & 3.1 & 0.57 & 3.1 & 0.57 \\
\hline 6 & 2007 & $\mathrm{~F}$ & $\mathrm{IH}$ & 1.5 & 0.50 & 5.0 & 0.60 & & & & & & & & \\
\hline 7 & 2007 & $\mathrm{M}$ & MPHD & 2.9 & 0.43 & 3.7 & 0.50 & ${ }^{\#} 13$ & 2002 & $\mathrm{~F}$ & MPHD & 6.2 & 0.58 & & \\
\hline
\end{tabular}

CH-C, congenital hypothyroidism of central origin; FT4, free T4; M, male; F, female; IH, isolated central hypothyroidism; MPHD, multiple pituitary hormone deficiency ${ }^{\#}$ Pt.13 was identified by observation of shock in the neonatal period with a positive FT4 level result, whereas all other patients were identified solely via newborn screening.

Table 2 Transient CH-C patients with positive FT4 screening results

\begin{tabular}{|c|c|c|c|c|c|c|c|c|c|c|}
\hline \multirow{3}{*}{$\begin{array}{l}\text { Pt. } \\
\text { No. }\end{array}$} & \multirow{3}{*}{$\begin{array}{l}\text { Birth } \\
\text { year }\end{array}$} & \multirow{3}{*}{ Sex } & \multirow{3}{*}{$\begin{array}{l}\text { Birth } \\
\text { weight } \\
\text { (g) }\end{array}$} & \multicolumn{4}{|c|}{ Screening results with sampling age } & \multirow{2}{*}{\multicolumn{3}{|c|}{ Information about maternal Graves' disease }} \\
\hline & & & & \multicolumn{2}{|c|}{ First sample } & \multicolumn{2}{|c|}{ Second sample } & & & \\
\hline & & & & $\begin{array}{c}\text { TSH } \\
(\mu \mathrm{IU} / \mathrm{mL})\end{array}$ & $\begin{array}{c}\text { FT4 } \\
(\mathrm{ng} / \mathrm{dL})\end{array}$ & $\begin{array}{c}\text { TSH } \\
(\mu \mathrm{IU} / \mathrm{mL})\end{array}$ & $\begin{array}{c}\text { FT4 } \\
(\mathrm{ng} / \mathrm{dL})\end{array}$ & Onset & Diagnosis & Treatment \\
\hline \multirow{2}{*}{${ }^{\#+} 14$} & \multirow{2}{*}{1999} & \multirow{2}{*}{$\mathrm{F}$} & \multirow{2}{*}{3,142} & 0.3 & 0.48 & 2.7 & 0.61 & \multirow{2}{*}{ Unknown } & \multirow{2}{*}{$\begin{array}{l}\text { Never diagnosed until } \\
\text { newborn screening. }\end{array}$} & \multirow{2}{*}{ None } \\
\hline & & & & \multicolumn{2}{|c|}{ (5 days old) } & \multicolumn{2}{|c|}{ (28 days old) } & & & \\
\hline \multirow{2}{*}{15} & \multirow{2}{*}{2004} & \multirow{2}{*}{ M } & \multirow{2}{*}{3,348} & 1.7 & 0.45 & 2.2 & 0.48 & \multirow{2}{*}{ Unknown } & \multirow{2}{*}{$\begin{array}{l}\text { Already diagnosed } \\
\text { during pregnancy }\end{array}$} & \multirow{2}{*}{$\begin{array}{c}\text { Provided } \\
\text { (details unknown) }\end{array}$} \\
\hline & & & & \multicolumn{2}{|c|}{ (5 days old) } & \multicolumn{2}{|c|}{ (20 days old) } & & & \\
\hline \multirow{2}{*}{ \#16 } & \multirow{2}{*}{2004} & \multirow{2}{*}{ M } & \multirow{2}{*}{3,395} & 4.2 & 0.20 & 2.4 & 0.55 & \multirow{2}{*}{ Unknown } & \multirow{2}{*}{ Unknown } & \multirow{2}{*}{ Unknown } \\
\hline & & & & \multicolumn{2}{|c|}{ (6 days old) } & \multicolumn{2}{|c|}{ (18 days old) } & & & \\
\hline \multirow{2}{*}{${ }^{\#} 17$} & \multirow{2}{*}{2006} & $\mathrm{~F}$ & 2790 & 2.4 & 0.46 & 3.7 & 0.69 & 3rd trimester. & Never diagnosed until & None \\
\hline & & & $2, / 90$ & (5 day & ld) & $(14 \mathrm{dc}$ & old) & (estimated) & newborn screening. & None \\
\hline \#18 & 2008 & $\mathrm{~F}$ & 3,185 & 1.7 & 0.69 & 3.8 & 0.51 & Unknown & Never diagnosed until & None \\
\hline & & $F$ & 3,185 & (4 day & ld) & $(13 \mathrm{dc}$ & old) & Unknown & newborn screening. & \\
\hline
\end{tabular}

CH-C, congenital hypothyroidism of central origin; FT4, free T4; M, male; F, female

\# In these patients, thyroid function was evaluated solely because of the detection of low FT4 levels during newborn screening.

${ }^{+}$In patient 14 , transition from $\mathrm{CH}-\mathrm{C}$ to thyroidal hypothyroidism was later observed.

\section{Efficacy of the screening system involving FT4 level measurement}

The use of the FT4 screening system allowed for the identification of 24 true-positive cases, yielding a detection rate of $24 / 740,003$ or 1 in 30,833 births.

\section{Discussion}

Transient $\mathrm{CH}-\mathrm{C}$ occurs in infants born to mothers who develop hyperthyroidism during their pregnancy because of inadequately treated Graves' disease [7-11]. As shown in Table 2, 5 cases of transient CH-C were identified by the measurement of low FT4 levels through newborn screening. To our knowledge, this is the first systematic audit of transient $\mathrm{CH}-\mathrm{C}$ patients identified through FT4 screening.
As observed in our patients, FT4 levels in transient $\mathrm{CH}-\mathrm{C}$ may be markedly low [7-11], and hypothyroidism in transient $\mathrm{CH}-\mathrm{C}$ may persist for more than 1 year $[8,11]$. In addition, the transition from $\mathrm{CH}-\mathrm{C}$ to $\mathrm{CH}-\mathrm{T}$ due to thyroid disintegration has been reported, similar to that noted in patient 14 in the present study [10]. Accordingly, failure to identify and treat this condition will likely result in serious intellectual disabilities [11]. Of the 5 patients with transient $\mathrm{CH}-\mathrm{C}, 4$ (patients 14, 16, 17, and 18 in Table 2) did not undergo thyroid function evaluation until the screening results had been reported. In other words, these 4 patients may have been overlooked if they had not undergone FT4 screening. It is of particular interest that in 3 patients (patients 14, 17, and 18), Graves' disease in the mother had not been recognized until transient $\mathrm{CH}-\mathrm{C}$ was diagnosed 
Table 3 Patients with primary hypothyroidism with delayed TSH level elevation who were detected due to low FT4 levels during newborn screening

\begin{tabular}{|c|c|c|c|c|c|c|c|c|c|c|c|c|c|}
\hline \multirow{3}{*}{$\begin{array}{l}\text { Pt. } \\
\text { No. }\end{array}$} & \multirow{3}{*}{$\begin{array}{l}\text { Birth } \\
\text { year }\end{array}$} & \multirow{3}{*}{\multicolumn{2}{|c|}{$\begin{array}{c}\text { Birth } \\
\text { Sex weight } \\
\text { (g) }\end{array}$}} & \multirow{3}{*}{$\begin{array}{c}\text { Birth } \\
\text { weeks }\end{array}$} & \multicolumn{6}{|c|}{ Screening results with sampling age } & \multirow{2}{*}{\multicolumn{2}{|c|}{$\begin{array}{l}\text { Confirmation result } \\
\text { (age) }\end{array}$}} & \multirow{3}{*}{${ }^{\#}$ Underlying disease } \\
\hline & & & & & \multicolumn{2}{|c|}{${ }^{+}$Preliminary sample } & \multicolumn{2}{|c|}{ First sample } & \multicolumn{2}{|c|}{ Second sample } & & & \\
\hline & & & & & $\begin{array}{c}\text { TSH } \\
(\mu \mathrm{IU} / \mathrm{mL})\end{array}$ & $\begin{array}{c}\text { FT4 } \\
(\mathrm{ng} / \mathrm{dL})\end{array}$ & $\begin{array}{c}\text { TSH } \\
(\mu \mathrm{IU} / \mathrm{mL})\end{array}$ & $\begin{array}{c}\text { FT4 } \\
\text { (ng/dL) }\end{array}$ & $\begin{array}{c}\text { TSH } \\
(\mu \mathrm{IU} / \mathrm{mL})\end{array}$ & $\begin{array}{c}\text { FT4 } \\
\text { (ng/dL) }\end{array}$ & $\begin{array}{c}\text { TSH } \\
(\mu \mathrm{IU} / \mathrm{mL})\end{array}$ & $\begin{array}{c}\text { FT4 } \\
\text { (ng/dL) }\end{array}$ & \\
\hline \multirow{2}{*}{19} & \multirow{2}{*}{2001} & \multirow[t]{2}{*}{ 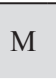 } & \multirow{2}{*}{2,258} & \multirow{2}{*}{36} & & \multirow[b]{2}{*}{$\begin{array}{lll}- & - \\
-1\end{array}$} & 2.1 & 0.09 & 19.8 & 0.37 & $14.3\left[{ }^{*} 119.9\right]$ & 0.80 & Massi \\
\hline & & & & & & & (5 days & old) & \multicolumn{2}{|c|}{ (16 days old) } & \multicolumn{2}{|c|}{ (24 days old) } & \\
\hline \multirow{2}{*}{20} & \multirow{2}{*}{2001} & \multirow{2}{*}{$\mathrm{F}$} & \multirow{2}{*}{3,170} & \multirow{2}{*}{41} & & \multirow{2}{*}{ - } & & 0.15 & 19.5 & 1.26 & 30.4 & 1.10 & $\mathrm{Nec}$ \\
\hline & & & & & & & (6 days & old) & \multicolumn{2}{|c|}{ (15 days old) } & \multicolumn{2}{|c|}{ (24 days old) } & ve \\
\hline \multirow{2}{*}{21} & \multirow{2}{*}{2003} & \multirow{2}{*}{$\mathrm{F}$} & \multirow{2}{*}{2,733} & \multirow{2}{*}{33} & & \multirow[b]{2}{*}{ 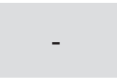 } & 9.4 & 0.54 & 31.0 & 1.19 & 120.6 & 0.80 & $\mathrm{Co}$ \\
\hline & & & & & & & $(5 \mathrm{~d} a$ & old) & $(13 \mathrm{~d}$ & old) & $\left(20 d_{i}\right.$ & ld) & \\
\hline 22 & 2004 & F & 1.902 & 3 & 5.9 & 1.87 & 6.9 & 0.68 & 27.6 & 0.67 & 39.6 & 0.85 & Low birth weight \\
\hline 22 & 2004 & $\Gamma$ & 1,902 & 32 & $(5 \mathrm{da}$ & ld) & $(29 \mathrm{da}$ & s old) & $(37 \mathrm{~d} c$ & old) & (41 days & old) & \\
\hline & & & & & 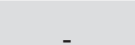 & & & 0.64 & 25.6 & 1.24 & 35.2 & 1.42 & \\
\hline 23 & 2005 & M & & 39 & $\begin{array}{ll}- & -\end{array}$ & - & $(5 \mathrm{da}$ & old) & $(16 \mathrm{~d}$ & old) & (17 days & old) & \\
\hline$\star_{24}$ & 2004 & $\mathrm{~F}$ & 1,074 & 31 & 4.3 & 0.33 & 3.0 & 0.66 & 2.5 & 0.39 & $8.92\left[{ }^{*} 44.6\right]$ & Unknown & Low \\
\hline & & & & & (6 days & old) & (31 day & s old) & (40 day & s old) & (6 years & old) & \\
\hline
\end{tabular}

FT4, free T4; M, male; F, female

${ }^{+}$In newborns with a birth weight $<2,000 \mathrm{~g}$, an initial filter paper sample is treated as preliminary, and the first sample is requested at approximately 1 month of age.

${ }^{\#}$ All patients admitted to neonatal intensive care unit soon after birth because of each underlying disease.

${ }^{*}$ TSH values obtained following thyrotropin-releasing hormone stimulation.

$\$$ In patient 24 , hypoplastic thyroid gland was later documented.

in the newborns. We are aware of 4 additional similar cases in the NMC-KPMA database, in which the newborns were born after the study period (unpublished data); this situation was also previously described in a US patient [9].

When maternal Graves' disease is recognized prior to conception, pertinent treatment may be provided during pregnancy, and $\mathrm{CH}-\mathrm{C}$ is not likely to develop in newborns. However, when maternal Graves' disease develops during pregnancy, the features of hyperthyroidism may go unnoticed by obstetricians. The resulting untreated Graves' disease increases the risk of transient $\mathrm{CH}-\mathrm{C}$ in newborns, and even worse, this risk cannot be discernible by pediatricians and/or neonatologists.

Based on the above findings, we believe that this condition qualifies as a target entity of newborn screening, because the level of risk posed by transient $\mathrm{CH}-\mathrm{C}$ is sufficiently high and screening by FT4 measurement can facilitate identification of patients for prompt treatment. In addition, through this screening, the real incidence of maternal Graves' disease with onset during pregnancy may become evident.

$\mathrm{CH}-\mathrm{T}$ with delayed TSH elevation has been described mainly in preterm newborns (especially in newborns with a gestational age of $<37$ weeks), LBW newborns, sick and preterm newborns admitted to the
NICU, and newborns from multiple births [4, 12-16]. In these situations, the diagnosis of $\mathrm{CH}-\mathrm{T}$ may be overlooked due to the suppression of the TSH level as a result of various drugs, hypothalamo-pituitary immaturity, and other effects of serious illness [17, 18].

Although thyroid dysfunction in these patients may be mild and/or transient, and long-term outcome data are scarce, according to a recent review, appropriate treatment should be considered in these patients [17]. In a series reported by Woo et al., 16\% of patients with $\mathrm{CH}-\mathrm{T}$ with delayed TSH elevation had a TSH level $>50 \mu \mathrm{IU} / \mathrm{mL}$ [12]. This indicates that at least a small portion of these patients may have moderate to severe hypothyroidism.

Based on such findings, the need to detect this condition through newborn screening has been globally recognized. For this purpose, repetitive TSH level measurement is recommended for preterm and/or LBW newborns [14-16]. In Kanagawa Prefecture, an additional filter paper sampling is routinely requested for newborns with a birth weight of $<2,000 \mathrm{~g}$ at approximately 1 month of age, and this sample is treated as the first sample.

As shown in Table 3, 6 cases of $\mathrm{CH}-\mathrm{T}$ with delayed TSH elevation were detected by the measurement of low FT4 level with normal TSH level in the first 
screening sample. Two of them (patient 20 and 23) were mature patients. According to the strict definition, they should not be included in the $\mathrm{CH}-\mathrm{T}$ with delayed TSH elevation category, because this concept has been considered mainly in premature and/or LBW newborns and non-thyroidal illness cannot be excluded in these 2 patients. However, in the present study, we included these patients in this category because it is evident that they benefited from the FT4 screening. In addition, the presence of $\mathrm{CH}-\mathrm{T}$ is probable in these patients, considering high TSH levels $(30.4 \mu \mathrm{IU} / \mathrm{mL}$ and $35.2 \mu \mathrm{IU} / \mathrm{mL}$, respectively) at the confirmatory testing (Table 3 ).

Two mature newborns mentioned above (patient 20 and 23) and two other newborns (patient 19 and 21) may have been checked by TSH screening alone, if repetitive filter paper sampling in every sick newborn were mandatory. However, in reality, routine request for repetitive sampling for all sick newborns seems to be impractical, considering the higher screening cost and the increased burden of medical staff.

Remaining 2 were infants with a birth weight of $<2,000 \mathrm{~g}$ from whom the first sample had been obtained at approximately 1 month of age, indicating that more than a month was required for their TSH level to recover from suppression. Thus, these results suggest that FT4 measurement allows for the detection of $\mathrm{CH}-\mathrm{T}$ with delayed TSH elevation in newborns experiencing markedly slow TSH recovery, as well as in new- borns with TSH suppression due to critical illness.

The identification of 24 true-positives over the study period yields a detection rate of 1 in 30,833 births, which is similar to the incidence of congenital adrenal hyperplasia ( 1 in 18,000 births) and exceeds that of phenylketonuria (1 in 114,379 births) in Japan [19, 20]. Screening for $\mathrm{CH}-\mathrm{C}$ was formerly criticized as inefficient because of the rarity of $\mathrm{CH}-\mathrm{C}$, but it is now recognized that $\mathrm{CH}-\mathrm{C}$ is more prevalent than previously thought $[6,21,22]$. Following the inclusion of transient $\mathrm{CH}-\mathrm{C}$ and $\mathrm{CH}-\mathrm{T}$ with delayed TSH elevation as the target entities for screening with FT4 measurement, this system may be considered to be more efficient than currently thought.

In conclusion, our study revealed that use of the FT4 screening system allows for the identification of a substantial number of cases of transient $\mathrm{CH}-\mathrm{C}$ and $\mathrm{CH}-\mathrm{T}$ with delayed TSH elevation. This is a clear advantage of the simultaneous measurement of FT4 and TSH. We insist that this strategy should be evaluated under the condition where these entities are included as targets of screening.

\section{Conflict of Interest}

None of the authors have any potential conflicts of interest associated with this research.

\section{References}

1. Grosse SD, Van Vliet G (2011) Prevention of intellectual disability through screening for congenital hypothyroidism: how much and at what level? Arch Dis Child 96: 374-379.

2. LaFranchi SH (2011) Approach to the diagnosis and treatment of neonatal hypothyroidism. J Clin Endocrinol Metab 96: 2959-2967.

3. Rose SR, Brown RS, Foley T, Kaplowitz PB, Kaye CI, et al. (2006) Update of newborn screening and therapy for congenital hypothyroidism. Pediatrics 117: 2290 2303.

4. Léger J, Olivieri A, Donaldson M, Torresani T, Krude H, et al. (2014) European Society for Paediatric Endocrinology consensus guidelines on screening, diagnosis, and management of congenital hypothyroidism. J Clin Endocrinol Metab 99: 363-384.

5. Dias VM, Campos AP, Chagas AJ, Silva RM (2010) Congenital hypothyroidism: etiology. $J$ Pediatr Endocrinol Metab 23: 815-826.
6. Adachi M, Soneda A, Asakura Y, Muroya K, Yamagami Y, et al. (2012) Mass screening of newborns for congenital hypothyroidism of central origin by free thyroxine measurement of blood samples on filter paper. Eur $J$ Endocrinol 166: 829-838.

7. Matsuura N, Harada S, Ohyama Y, Shibayama K, Fukushi M, et al. (1997) The mechanisms of transient hypothyroxinemia in infants born to mothers with Graves' disease. Pediatr Res 42: 214-218.

8. Higuchi R, Miyawaki M, Kumagai T, Okutani T, Shima Y, et al. (2005) Central hypothyroidism in infants who were born to mothers with thyrotoxicosis before 32 weeks' gestation: 3 cases. Pediatrics 115: e623-e625.

9. Slyper AH, Shaker JL (1993) Neonatal hypothyroxinemia with normal thyrotropin. Clue to maternal Graves' disease. Clin Pediatr (Phila) 32: 121-123.

10. Kempers MJ, van Trotsenburg AS, van Rijn RR, Smets AM, Smit BJ, et al. (2007) Loss of integrity of thyroid morphology and function in children born to moth- 
ers with inadequately treated Graves' disease. J Clin Endocrinol Metab 92: 2984-2991.

11. Hotsubo T, Mori T, Wakai S, Tanabe C, Kamasaki H, et al. (1998) Central hypothyroidism with severely delayed myelination in a boy born to a mother with untreated Graves' disease. Clin Pediatr Endocrinol 7: 13-16.

12. Woo HC, Lizarda A, Tucker R, Mitchell ML, Vohr B, et al. (2011) Congenital hypothyroidism with a delayed thyroid-stimulating hormone elevation in very premature infants: incidence and growth and developmental outcomes. J Pediatr 158: 538-542.

13. Mandel SJ, Hermos RJ, Larson CA, Prigozhin AB, Rojas DA, et al. (2000) Atypical hypothyroidism and the very low birthweight infant. Thyroid 10: 693-695.

14. LaFranchi SH, Hanna CE, Krainz PL, Skeels MR, Miyahira RS, et al. (1985) Screening for congenital hypothyroidism with specimen collection at two time periods: results of the Northwest Regional Screening Program. Pediatrics 76: 734-740.

15. Rapaport R (2003) Evaluation of thyroid status of infants in intensive care settings: recommended an extension of newborn screening. J Pediatr 143: 556558.

16. Bijarnia S, Wilcken B, Wiley VC (2011) Newborn screening for congenital hypothyroidism in very-low- birth-weight babies: the need for a second test. $J$ Inherit Metab Dis 34: 827-833.

17. Fisher DA (2007) Thyroid function and dysfunction in premature infants. Pediatr Endocrinol Rev 4: 317-328.

18. Larson C, Hermos R, Delaney A, Daley D, Mitchell M (2003) Risk factors associated with delayed thyrotropin elevations in congenital hypothyroidism. J Pediatr 143: 587-591.

19. Tajima T, Fujikura K, Fukushi M, Hotsubo T, Mitsuhashi Y (2012) Neonatal screening for congenital adrenal hyperplasia in Japan. Pediatr Endocrinol Rev 10 Suppl 1: $72-78$.

20. Kitagawa T (2012) Newborn screening for inborn errors of metabolism in Japan. A history of the development of newborn screening. Pediatr Endocrinol Rev 10 Suppl 1: 8-25.

21. van Tijn DA, de Vijlder JJ, Verbeeten B Jr, Verkerk PH, Vulsma T (2005) Neonatal detection of congenital hypothyroidism of central origin. J Clin Endocrinol Metab 90: 3350-3359.

22. Fujiwara F, Fujikura K, Okuhara K, Tsubaki J, Fukushi $\mathrm{M}$, et al. (2008) Central congenital hypothyroidism detected by neonatal screening in Sapporo, Japan (20002004): It's Prevalence and Clinical Characteristics. Clin Pediatr Endocrinol 17: 65-69. 